\title{
Flooding and Earthquake Risk Interpretation for Kutahya Province, Turkey, Using ASTER DEM
}

\author{
Umut Erdem $^{1} \&$ Ali Can Demirkesen ${ }^{1}$ \\ ${ }^{1}$ Department of City \& Regional Planning, Izmir Institute of Technology, Izmir, Turkey \\ Correspondence: Umut Erdem, Department of City \& Regional Planning, Izmir Institute of Technology, Izmir, \\ Turkey. Tel: 90-232-750-7092. E-mail: umuterdem@iyte.edu.tr
}

Received: May 29, 2014 Accepted: June 30, 2014 Online Published: July 23, 2014

doi:10.5539/jgg.v6n3p133 URL: http://dx.doi.org/10.5539/jgg.v6n3p133

\begin{abstract}
Kutahya Province is a significant cultural heritage area of Turkey; it is susceptible to flooding when sudden heavy rain falls and is located in a high-risk earthquake region. The objective of this study was to acquire geo-information from Kutahya Province and interpret the risk levels to the population from floods and earthquakes. In this study, the Advanced Space-borne Thermal Emission Reflection Digital Elevation Model of Kutahya Province was used to create maps that illustrate the digital terrain model and the 3D fly-through dynamic model of the study region. The maps exhibit landform characteristics, fault zones, earthquake locations, thermal locations, stream drainages and water-flow accumulation areas. From the interpretation of the maps, the results revealed that the most susceptible areas to flooding are the settlements and agricultural plains of Kutahya, Altintas, and Simav, in decreasing order. Gediz, Simav, Kutahya, Emet, Tavsanli, Dumlupinar, Domanic, Hisarcik, Pazarlar and Saphane are at high risk of earthquake damage, in decreasing order. The results of this study can help planners involved in regional urban and infrastructure development as well as environmental planning in Kutahya province.
\end{abstract}

Keywords: natural hazard risk interpretation, flooding hazard risk, earthquake hazard risk, digital terrain analysis, Kutahya Turkey

\section{Introduction}

Kutahya Province, one of Turkey's most significant cultural heritage sites, is located in a high-risk earthquake region that is also susceptible to flooding caused by sudden heavy rains (Tabban, 2000; Taymaz et al., 2007; Korkmaz, 2009; AFAD, 2013; KOERI, 2013). Records of flooding events in Kutahya Province show that since 1940 there have been 38 flooding disasters that resulted in loss of lives and property (MGM, 2013). Since 1900, 64 earthquakes greater than the Richter scale, $M=5.0$ have occurred in Kutahya Province (Tabban 2000; Yilmaz \& Bagci, 2006; Taymaz et al., 2007; Korkmaz, 2009; AFAD, 2013; KOERI, 2013). In particular, the $M=7.1$ Gediz earthquake in 1970 resulted in loss of lives and property. About 10,000 buildings have damaged or destroyed; about 1000 people have lost and about 1500 people have injured (Penzien \& Hanson, 1970). And, the $\mathrm{M}=5.9$ Simav earthquake in 2011 resulted in loss of lives and property, as well. About 100 buildings have collapsed; about 300 buildings have damaged; 2 people have lost; about 100 people have injured (Zulfikar et al., 2011). These natural disasters highlight the area's high susceptibility to flood and earthquake damages.

One of the most important and common issues faced by policy-makers is the threat of natural disasters that can lead to high social and economic costs. Therefore, policy-makers need analysis tools and models to improve their decision-making processes to minimize the adverse effects of the natural disasters. The natural hazards discussed in this study are divided into two fields: meteorology-based flooding due to heavy rain caused by changing climate patterns and geology-based earthquake hazards caused by tectonic activities.

While historical records of Kutahya Province show that the region's population is under considerable threat from flooding and earthquakes, a literature review reveals that there are few studies that focus on analyses of the geological characteristics of Kutahya Province in terms of natural hazard risks. But, some studies have investigated flooding hazard risks similar to those discussed in our study. For example, Wolock and Price (1994) investigated the effects of a digital elevation model, map scale, and data resolution on a topography-based watershed model. Van der Sande et al. (2003) studied the flooding risk and flood damage interpretation. They created land cover maps from high resolution satellite imagery, the IKONOS to assist flood risk and flood 
damage interpretation. Wang et al. (2002) used Landsat Thematic Mapper (TM) and Digital Elevation Model (DEM) data for mapping flood extent in a coastal flood plain. They describe an efficient and reliable method for mapping flooding areas in a coastal flood plain and modeling inundation using DEM data.

The objective of this study was to acquire geo-information about Kutahya Province of Turkey and describe the flood and earthquake risk levels to towns and cities in the region. Our main data source was the Advanced Space-borne Thermal Emission Reflection Global Digital Elevation Model (ASTER GDEM) of Kutahya Province. Besides, previous natural disasters and existing landscape characteristics were also analyzed for risk interpretations. By quantifying and analyzing the Digital Terrain Model (DTM) (Wilson and Gallant 2000) geo-information of Kutahya Province was acquired. This acquired geo-information would help to (i) control and extend the existing natural hazard precaution and prevention measures; (ii) evaluate the suitability and flexibility of current regional development plan strategies with regard to natural hazards; and (iii) assist in decision-making regarding future land planning in the study area. In this study, the main river drainage patterns that indicate flood risk areas, water-flow accumulation areas that indicate flood-prone zones, the locations of known fault lines and thermal zones indicating volcanism and geo-tectonic activities and earthquake risk areas were investigated.

The results have important implications for environmental planning in Kutahya Province, where natural hazards such as floods and earthquakes are a significant concern. This study also demonstrates the use of digital terrain analysis, DEM classification, and extraction of river drainage patterns and water-flow accumulation areas using a geographic information system (GIS).
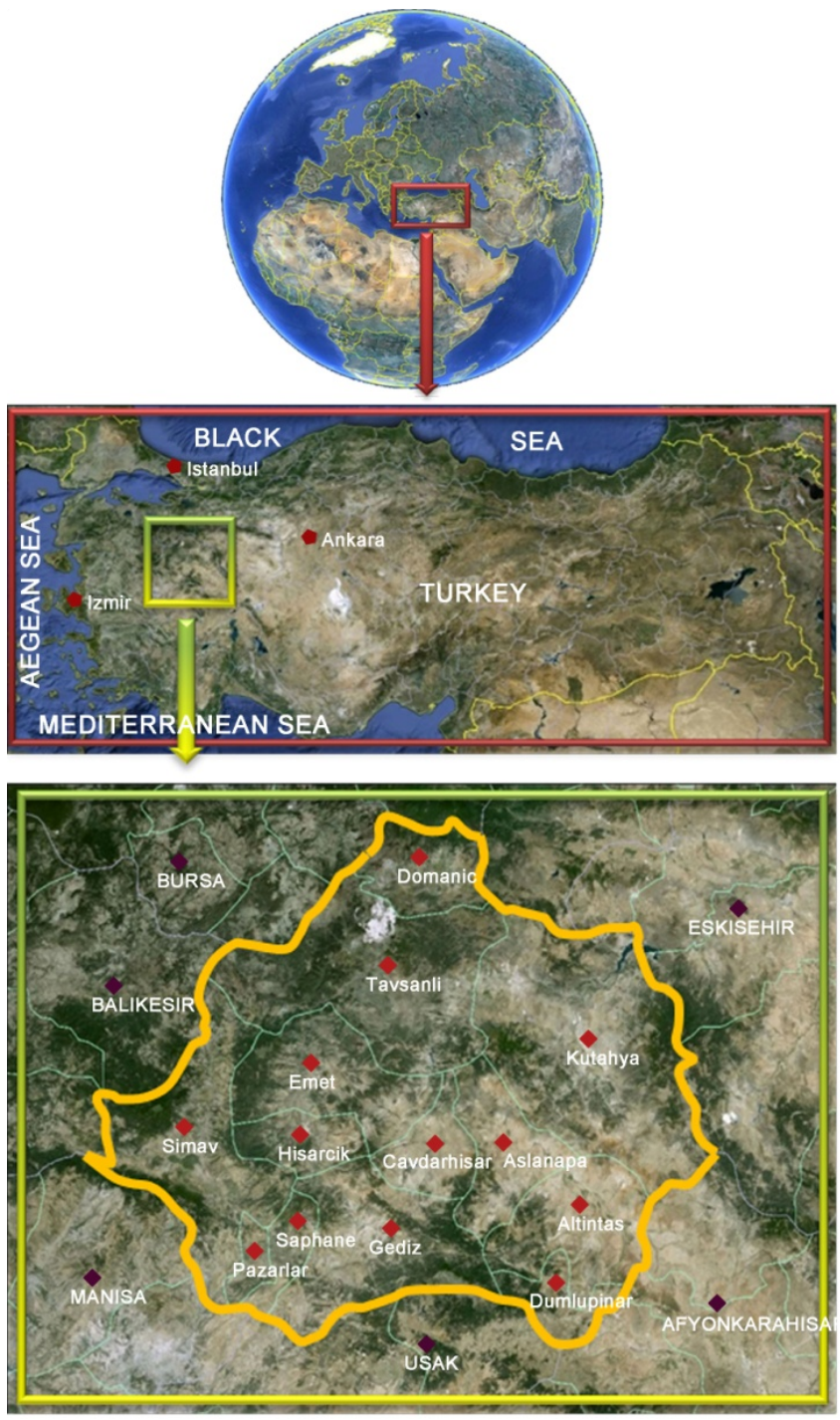

Figure 1. Location of the study region, Kutahya Province in Turkey 


\section{Materials and Methods}

\subsection{Study Region}

Kutahya Province is located on the western side of central Anatolia, in the Aegean region of the country (Figure 1 ), and covers an area of $11,977 \mathrm{~km}^{2}$. It lies between $38^{\circ} 70^{\prime}$ and $39^{\circ} 80^{\prime} \mathrm{N}$ and $29^{\circ} 00^{\prime}$ and $30^{\circ} 30^{\prime} \mathrm{E}$. It is surrounded by the provinces of Bursa and Bilecik to the north; Eskisehir to the east; Afyonkarahisar to the southeast; Usak to the south; Manisa to the southwest; and Balikesir to the west. The population of Kutahya Province was about 565,000 in 2012 (Atalay, 2008; TUIK, 2013).

According to regional information, Kutahya Province is a high-risk earthquake region (Tabban, 2000; Taymaz et al., 2007; Korkmaz, 2009; AFAD, 2013; Elmas \& Bentli, 2013; KOERI, 2013). It is located on the extension of the Aksehir fault zone (Bozkurt, 2001; Bilim, 2007) and includes a number of Tertiary fault zones such as the Kutahya, Simav, Emet, and Tavsanli fault zones (Bozkurt, 2001). The Gediz, Alasehir, and Aksehir earthquakes in the past years are evidence of the tectonic activities in and around the study region. The magnitude $\mathrm{M}=6.9$ Alasehir earthquake in Manisa Province, occurred in 1969, causing 53 deaths and destroying 3,700 houses. The most severe earthquake in the region occurred in 1970 within the Aksehir fault zone in Afyonkarahisar Province. The magnitude $\mathrm{M}=7.0$ event caused 1,100 deaths and injured 520 people (Yilmaz \& Bagci, 2006; AFAD, 2013; KOERI, 2013).

Table 1. Landscape characteristics of Kutahya Province (Atalay, 2008; GEODATA, 2013; TUIK, 2013)

\begin{tabular}{|c|c|c|c|c|c|c|}
\hline $\begin{array}{l}\text { Main } \\
\text { Settlements }\end{array}$ & $\begin{array}{r}\text { Population } \\
\text { of Settlements }\end{array}$ & Fault Zones & Main Valleys & Main Creeks & Main Lakes & $\begin{array}{l}\text { Mountains } \\
\text { (m) }\end{array}$ \\
\hline Kutahya & 238,000 & \multirow[t]{2}{*}{ Kutahya-Tavsanli } & \multirow{4}{*}{$\begin{array}{l}\text { Porsuk and } \\
\text { Frig Valleys in } \\
\text { Kutahya }\end{array}$} & \multirow{3}{*}{$\begin{array}{l}\text { Porsuk Creek in } \\
\text { Kutahya }\end{array}$} & Enne and & \multirow{4}{*}{$\begin{array}{l}\text { Turkmen } \\
(1826) \text { and } \\
\text { Yellice } \\
(1764)\end{array}$} \\
\hline Altıntas & 18,000 & & & & Porsuk Lakes & \\
\hline Aslanapa & 11.000 & \multirow[t]{2}{*}{ Eskisehir -Bilecik } & & & in Kutahya & \\
\hline Coulo & 11,000 & & & \multirow{4}{*}{$\begin{array}{l}\text { Kokar Creek in } \\
\text { Aslanapa, } \\
\text { Antıntas and } \\
\text { Dumlupinar }\end{array}$} & & \\
\hline Cavdarhisar & 8,000 & Simay - Gediz & Simav Valley & & Cavdarhisar & Mountains in \\
\hline Domanic & 16,000 & & in Simav & & Lake in & Kutahya \\
\hline Dumlupinar & 3,000 & \multirow{14}{*}{$\begin{array}{l}\text { Dumlupinar } \\
\text {-Hisarcik }\end{array}$} & & & Cavdarhisar & \\
\hline Emet & 22,000 & & Karasu Valley & & & Egrigoz \\
\hline Gediz & 52,000 & & and Tavsanli & Cavdarhisar and & $\begin{array}{l}\text { Simav Lake } \\
\text { in Simav }\end{array}$ & Mountain in \\
\hline Hisarcik & 14,000 & & & Tavsanli & & Emet \\
\hline Pazarlar & 6,000 & & Gediz Valley & & Kayabogazi & \\
\hline Simav & 68,000 & & in Gediz & Emet Creek in & Lake in & Murat (2303) \\
\hline Saphane & 8,000 & & & $\begin{array}{l}\text { Emet and } \\
\text { Hisarcik }\end{array}$ & Tavsanli & $\begin{array}{l}\text { Mountain in } \\
\text { Gediz }\end{array}$ \\
\hline \multirow[t]{7}{*}{ Tavsanli } & 101,000 & & Emet and & & & \\
\hline & & & Hisarcik & $\begin{array}{l}\text { Gediz Creek in } \\
\text { Gediz }\end{array}$ & & $\begin{array}{l}\text { Simav (1800) } \\
\text { and }\end{array}$ \\
\hline & & & & & & Ak (2089) \\
\hline & & & & $\begin{array}{l}\text { Simav Creek in } \\
\text { Simav }\end{array}$ & & $\begin{array}{l}\text { Mountains in } \\
\text { Simav }\end{array}$ \\
\hline & & & & & & Yesil (1533) \\
\hline & & & & & & Mountain in \\
\hline & & & & & & Tavsanli \\
\hline Total & 565,000 & & & & & \\
\hline
\end{tabular}

Geologically, more detailed regional-geological information can be found in Zulfikar et al. (2011). In general, Kutahya Province consists mostly of limestone formations and sediments, formed by rivers and floods. The plains in the region are mostly covered with alluvial soils. Groundwater can be found at a depth of about one meter under these alluvial soils. Therefore, the ground surface in these areas of alluvial soils would be at high 
risk of liquefaction if an earthquake occurs. The mountain areas comprise mostly limestone formations including crystalized limestone and metamorphosed marble in addition to the volcanic rock, tuffs, and ignimbrites of the Neogene period (about 20 million years ago) (Tabban, 2000).

Kutahya Province has rich thermal resources that indicate volcanic and geo-tectonic structures that are closely associated with fault zones and earthquakes. The major thermal resources are located in Yoncali, Ilicasu, Murat, Yesil, Kaynarca, Simav, Tavsanli, and Ilica. These thermal resources are used for heating houses and greenhouses in addition to producing electricity (Kose, 2005, 2007). The land cover and landscape characteristics of Kutahya Province are shown in Table 1 (Atalay, 2008; GEODATA, 2013; TUIK, 2013). Kutahya Province partly occupies three major river basins, those of the Sakarya, Gediz, and Susurluk rivers (Baykan, 2004; GEODATA, 2013).

About $50 \%$ of Kutahya Province consists of mountainous areas mostly covered by forests. Mount Murat, a volcanic formation, has the highest elevation in Kutahya Province at 2,309 m. The city of Kutahya is located on a fault zone just north of Mount Yellice $(1,764 \mathrm{~m})$. About $47 \%$ of Kutahya Province is covered with flat agricultural land of alluvial soils, which are under threat of flooding. In the study region, the Kutahya Plain is the largest agricultural plain with an area of $93 \mathrm{~km}^{2}$ and an altitude of about $930 \mathrm{~m}$ above sea level. About $1 \%$ of Kutahya Province is covered with lakes and rivers and groundwater is plentiful.

The study area is larger than the area of the Kutahya Province. In the study area, infact, plateau plains are $42 \%$ of Kutahya Province $\left(11,977 \mathrm{~km}^{2}\right)$. Mountains are $55 \%$. Water bodies are $1 \%$. And settlements are $2 \%$. The mountain areas are covered with mostly forest areas. The plateau areas are covered with mostly agriculture areas.

Table 2. DEM classification of the study area

\begin{tabular}{lrrl}
\hline Elevation classification & Area $\left.\mathbf{( k m}^{\mathbf{2}}\right)$ & Total $\mathbf{( \% )}$ & Dominant land cover types \\
\hline 7- 250 m Valley I & 1152.7 & 4.0 & Agriculture/settlement \\
$\mathbf{2 5 0 - 7 5 0}$ m Valley II & 12146.6 & 41.0 & Agriculture/settlement \\
$\mathbf{1 2 5 0 - 1 7 5 0}$ m High Plateau & 15281.5 & 51.0 & Agriculture/settlement \\
$\mathbf{1 2 5 0 - 1 7 5 0}$ m Mountain & 1083.2 & 3.9 & Bareground/forest \\
$\mathbf{1 7 5 0 - 2 3 0 3}$ m High Mountain & 29.8 & 0.1 & Forest/bareground \\
\hline Total & $\mathbf{2 9 , 6 9 3 . 8}$ & $\mathbf{1 0 0 . 0}$ & \\
\hline
\end{tabular}

Grid size resolution $=30 \mathrm{~m}$; horizontal accuracy $=15 \mathrm{~m}$; and vertical accuracy $=8 \mathrm{~m}$.

About 2\% of Kutahya Province is covered with built-up areas. There is no major river in the province. The main rivers are (i) a tributary of the Porsuk River with a length of $100 \mathrm{~km}$, (ii) the $35-\mathrm{km}$-long Murat River; (iii) a 45-km-long tributary of the Gediz River, and (iv) the Tavsanli River with a length of $65 \mathrm{~km}$. The lakes in the province are very small; the largest lake is Lake Simav with an area of $5 \mathrm{~km}^{2}$. Other lakes are the artificial ponds of Porsuk, Enne, Kayabogazi, and Cavdarhisar (Mitchell \& Glowatski, 1976; Atalay, 2008; Kutahya Governorship, 2013).

\subsection{Database Development}

The main dataset used in this study was the ASTER DEM data obtained from http://gdem.ersdac.jspacesystems.or.jp/search.jsp. The geographic coordinate system was the Universal Transverse Mercator (UTM) projection, zone 35N, WGS84 ellipsoid datum in 32-bit GeoTiff format. 


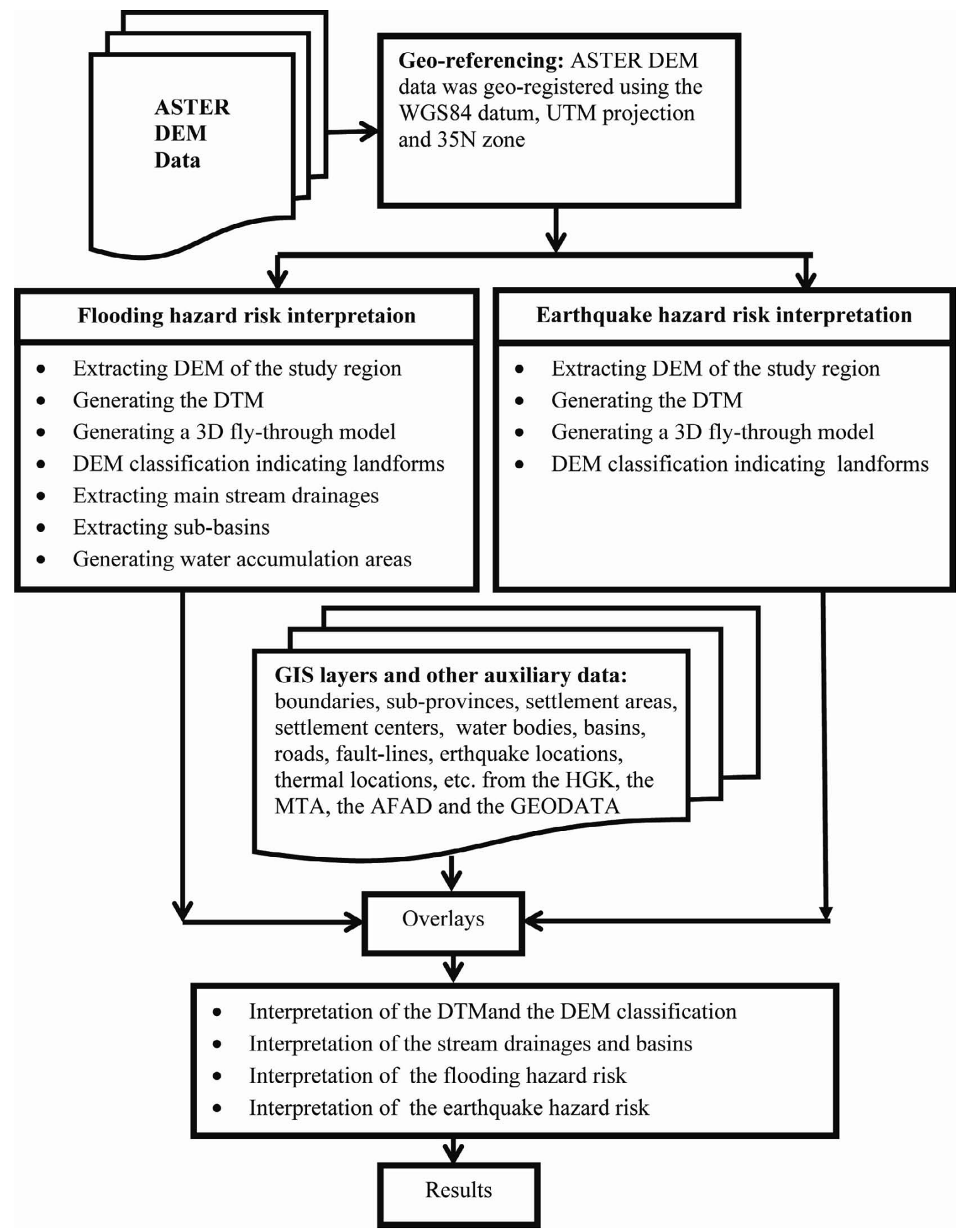

Figure 2. Methodology depicting the steps of the study

The ASTER DEM data have a spatial resolution of $30 \mathrm{~m}$, i.e., horizontal accuracy of $15 \mathrm{~m}$ and vertical accuracy of $8 \mathrm{~m}$ (San \& Suzen, 2005; ASTER GDEM, 2013; ERSDAC, 2013). In addition to the ASTER DEM data, the following sources were used: (i) 1:100,000 scale geographic maps obtained from the National Mapping Agency of Turkey (HGK, 2013); (ii) fault line maps obtained from the General Directorate of Mineral Research and Exploration (MTA, 2013); (iii) epicenter locations of earthquakes larger than the magnitude $\mathrm{M}=5.0$ that occurred since 1900, obtained from AFAD (2013) and KOERI (2013); (iv) data of rivers, creeks, and lakes obtained from Baykan (2004) and GEODATA (2013); (v) locations of thermal resources obtained from the 
provincial environmental report (KDEF, 2010); and (vi) boundaries of major river basins (Baykan, 2004; GEODATA, 2013) as auxiliary data sources. In addition to the 1:100,000 scale topographic maps of the HGK (2013), some auxiliary GIS layers from MTA (2013) and GEODATA (2013) were used in this study. These GIS layers include settlements, river basins, rivers, lakes, roads, fault lines, earthquake epicenter locations, thermal locations, and boundaries of sub-provinces of Kutahya Province.

\section{Data Processing for Analysis and Risk Interpretation}

The methodology used in this study was shown in Figure 2. The ASTER DEM data were used to produce flood and earthquake risk interpretation for the province. Before starting the interpretation, the Projection tool in ArcGIS to transform the DEM data from the World Reference System in geographic coordinates ( $\lambda$, $\varphi$; degrees) into the UTM projection system in Cartesian coordinates (x, y; meters) in UTM zone 35N and the WGS84 ellipsoid datum were used. Next, using the clip operation of the Raster tool in ArcGIS, the relevant DEM data were extracted according to a frame wider than the borders of Kutahya Province to evaluate the continuity of the landforms of the study region (ArcGIS, 2010).

For the flood risk interpretation, several operations on the DEM data were performed through the ArcGIS (ArcGIS, 2010). First, the DTM, a 24-bit color image of the shaded DEM data (Figure 3) was generated and analyzed by overlaying the settlements, creeks, river drainages, fault lines, and thermal locations, and a perspective view of the 3D fly-through dynamic model (Figure 4) was created. Then, the DEM data were classified to identify the main landforms such as valleys, plains, plateaus, hills, and mountains (Figure 5).

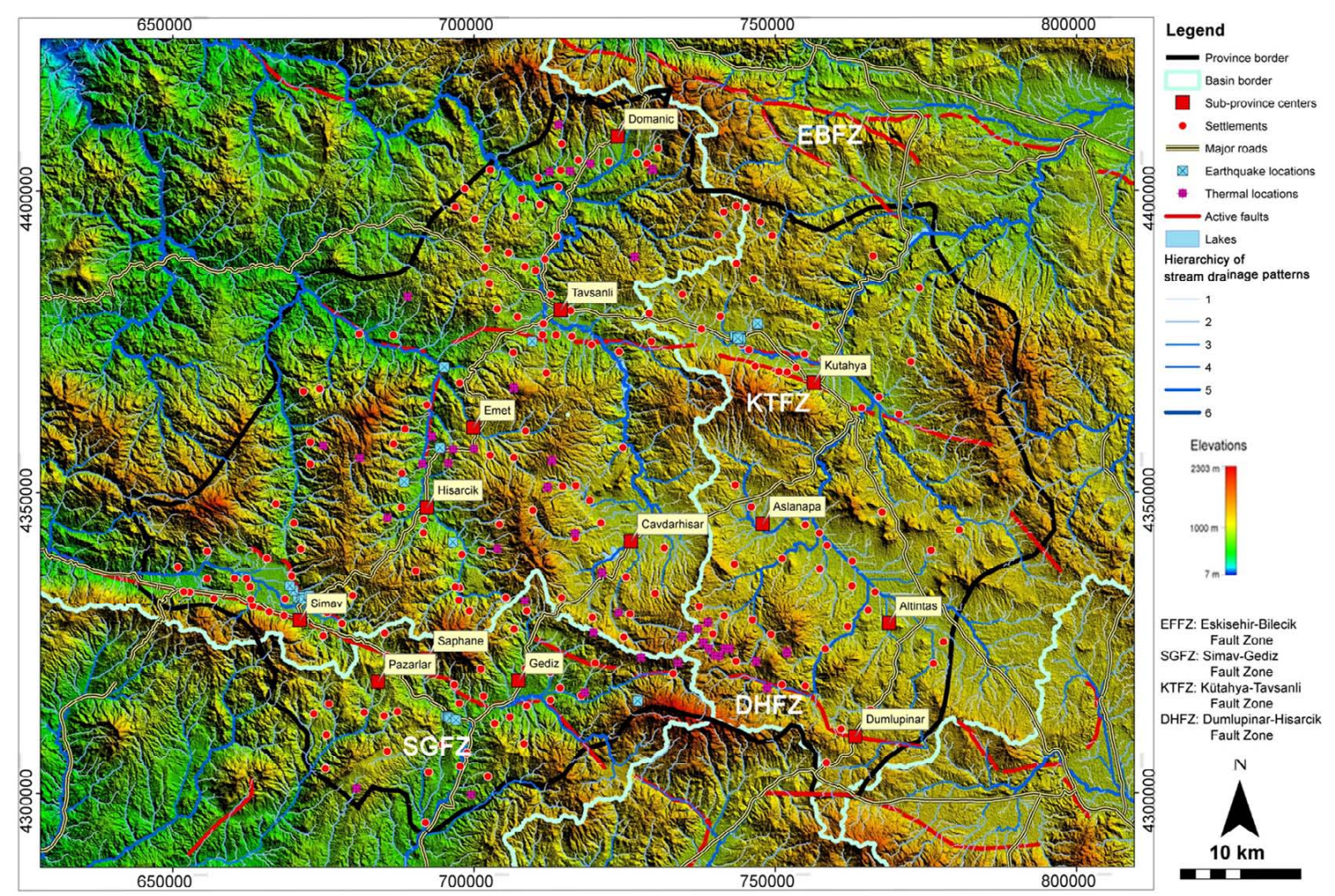

Figure 3. Main fault-lines and settlements overlaid with the DTM of Kutahya Province

This map was used for risk interpretation of flooding and earthquake hazards. As known, water flows from upper land to lower land and accumulates on flat plains and/or in deep valleys which are visualized by the DTM.

For the DEM classification, the elevation intervals were subjectively determined (i.e., user-determined) using the DEM visualization function in ArcGIS. These elevation classification intervals correspond to sudden color changes, slopes and aspects, which indicate a sudden change in the terrain surface, representing the borders of the valleys, plains, plateaus, hills, and mountains. Therefore, the classified elevation levels of the DEM and the number of intervals used in the analysis can vary depending on the user-defined thresholds. The elevation intervals were determined by examining the topographic characteristics of the surface of the study area. 
In this study, elevations of 7-250 m were classified as 'valleys-I'. Elevations of 250-750 m were classified as 'valleys-II'. Elevations of $50-1,250 \mathrm{~m}$ were classified as high plains, and elevations of 1,250-1,750 m were classified as plateaus. Elevations of 1,750-2,303 m were classified as mountains (Figure 5 and Table 2). Figure 5 shows a small number of height intervals within the elevation range of 7-2,303 m.
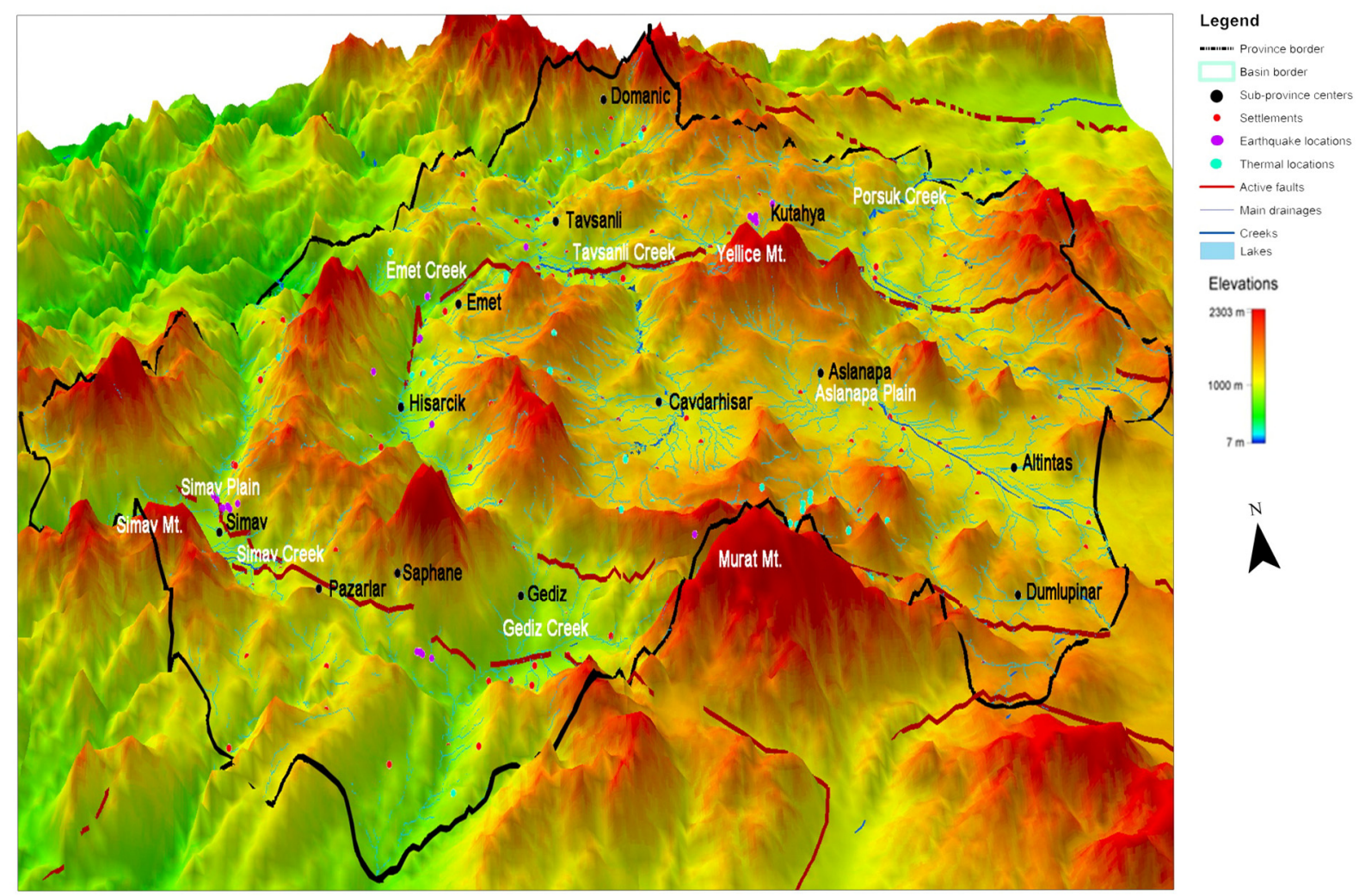

Figure 4. 3D fly-through model of the Kutahya Province

This model was used for risk interpretation of flooding and earthquake hazards for the settlements of the Kutahya Province.

The DEM classification (Figure 5) shows that the majority of the settlements in Kutahya Province are located in the flat, agricultural areas at an elevation of $750-1,250 \mathrm{~m}$. The earthquake epicenters are densely located at the foot of the mountains, where the mountain slopes meet the flat plains. The main river channels of Kutahya Province are located mostly in the valleys.

After the DEM classification of the geographical features (Figure 4) and analysis, maps of the main stream drainage hierarchy, i.e., stream orders (Figure 5 and Table 2), sub-basins (Figure 6 and Table 3), and water-flow accumulation areas (Figure 7), were generated from the ASTER DEM data via the Hydrology tool in ArcGIS (Mark et al., 19984; O’Callaghan \& Mark, 1984; Band, 1986; Ozdemir \& Bird, 2009). The sub-basins were categorized according to the major river basins of the Kutahya Province in the Environmental Atlas of Turkey (Baykan 2004).

For the flood risk analyses and interpretation, the outputs of the hydrological data processing, the DTM, the DEM classification, and a perspective view of the 3D fly-through model indicating landforms, sub-basins of major rivers, hierarchical stream drainages, and water-flow accumulation areas overlaid with the settlements, major roads, rivers, lakes, and sub-basin borders of Kutahya Province were used. Based on the analysis, flood-risk areas including Kutahya, Altintas, and Simav were illustrated in a map. Figure 7 shows the water-flow accumulation areas that indicate the main areas that have a high risk of flooding. The main river drainages overlaid with the settlements, sub-basins, lakes, and hierarchical stream drainages were analyzed and interpreted to determine which settlements are susceptible to flooding.

To analyze the hydrological features of Kutahya Province, the ASTER DEM data, which enabled us to analyze 
the drainage system hierarchy, basins, sub-basins, stream links, and water-flow accumulation areas were mainly used. In addition to the geo-information derived from the analysis of the ASTER DEM data, other auxiliary GIS data layers such as major roads, settlements, rivers/creeks, and major river basin borders were used for the flood risk interpretation process.

In the flooding risk interpretation process, five criteria were considered to determine the level of risk for settlements under threat of flooding. The criteria were (i) stream orders (hierarchies) of the main river channels; (ii) distance from settlements to the overflow zones of the main river channels, (iii) distance from settlements to the main river channels, (iv) slopes and aspects of the settlement areas and flat agricultural plains, and (v) distance from settlements to water flow accumulation areas.

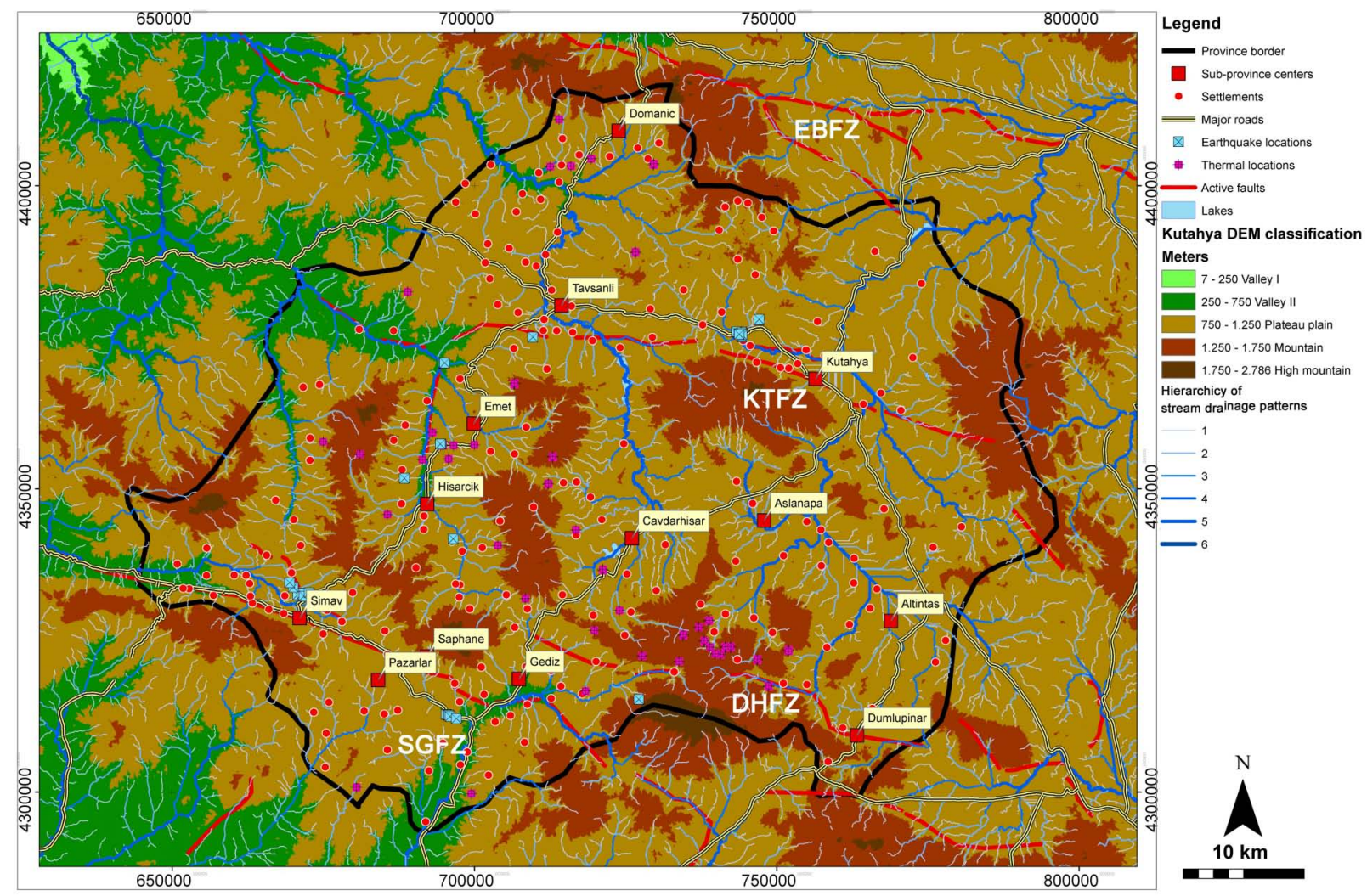

Figure 5. Main stream drainages and settlements overlaid on the ASTER DEM classification indicating landforms

This map was used for interpretation of flooding and earthquake hazard risks. Where EBFZ: Eskisehir - Bilecik Fault Zone, SGFZ: Simav - Gediz Fault Zone, KTFZ: Kutahya - Tavsanli Fault Zone, DHFZ: Dumlupinar Hisarcik Fault Zone.

For the earthquake risk interpretation, the DTM, the 3D fly-through dynamic model and the DEM classification were overlaid with the settlements and fault lines, earthquake locations, and thermal zones that indicate volcanic and geo-tectonic activities. Specifically, Quaternary fault lines (about 3 million years old), earthquake zones, locations with previous earthquakes of magnitude larger than $M=5.0$ since 1900, and the settlements located in Kutahya Province were overlaid. All the data were interpreted to describe relations and interactions among the landscape characteristics and the volcanic and tectonic structures in terms of earthquake risks.

In the earthquake risk interpretation, the earthquake risk levels of the settlements were described based on historical records of previous earthquakes (Tabban, 2000; Korkmaz, 2009). For example, the distances between previous earthquake locations and the earthquake magnitudes were considered as criteria to describe the risk level. In addition, the following criteria were also considered: (i) distance from the settlements to intersections of the main active fault lines; (ii) distance from the settlements to the main active fault lines; and (iii) ground surface and/or earth crust factors, such as rigid rocky areas, and alluvial soils prone to liquefaction, obtained 
from geological maps.

To determine the earthquake risks to towns and cities in the province, an additional criterion, the distance between the settlements and thermal locations, was also considered. This criterion has not been previously considered as an indicator of volcanic and geo-tectonic activities.

\section{Results and Discussion}

The analysis of the flood risk levels for the villages, towns, and cities of Kutahya Province and for the agricultural plain areas revealed that the main settlements and the agricultural plain areas of Kutahya, Altintas, and Simav (in decreasing order) as well as the villages in these regions and their surrounding areas have the highest risk of flooding. In particular, Inkoy and Seyitomer in Kutahya; Adakoy, Haydarlar, Nuhoren, Eymir, Cayirbasi, and Alayunt in Aslanapa; and Gulkoy and Guney in Simav and the town of Gobel in Tavsanli are most vulnerable to flooding caused by heavy rains.

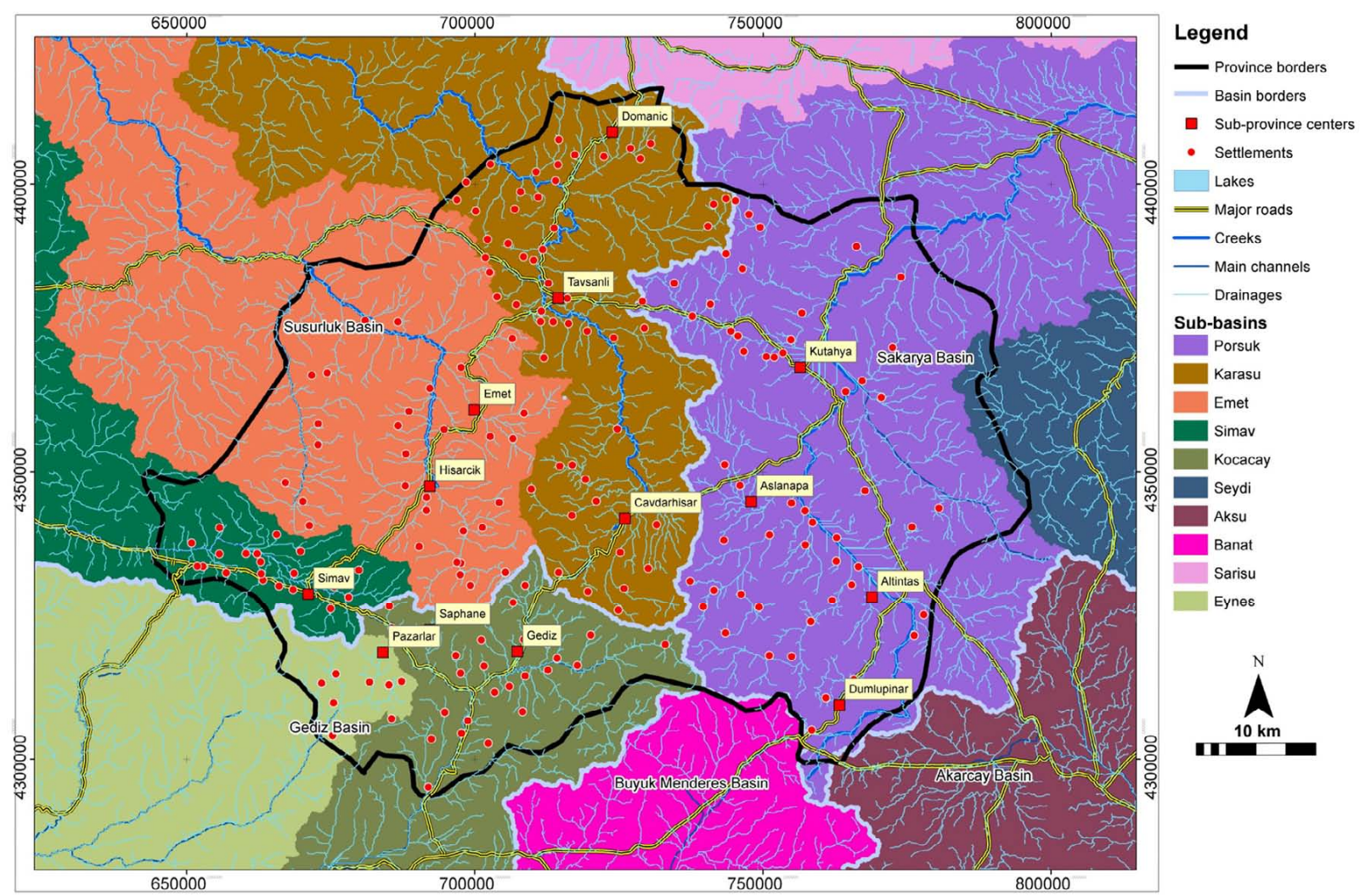

Figure 6. Main stream drainages and settlements overlaid on the sub-basins of the Kutahya Province

This map was used for interpretation of flooding hazard risk.

The study revealed that there are five main river drainage systems, consisting of the main river basins and sub-basins in the study region. The spatial distribution of the main river basins and their sub-basins (Figure 6 and Table 3) shows (i) the Porsuk River drainage system running in the sub-basin of the Porsuk River, which is part of the Sakarya River Basin; (ii) the Karasu Creek drainage system, running from north to south through the Karasu Creek sub-basin, which is part of the Susurluk River Basin; (iii) the Emet Creek drainage system running from north to southwest through the Emet Creek sub-basin, which is part of the Susurluk River Basin; (iv) the Gediz River drainage system in the Gediz River sub-basin running from east to northeast, which is part of the Gediz basin; and (v) the Kocacay Creek sub-basin drainage system in Simav, which is a sub-basin of the Susurluk River Basin. The Kocacay Creek runs from east to northeast, where a natural depression or collapse exists, indicating a fault line running from northeast to southwest. 
Table 3. Sub-basins of the study area generated from the ASTER DEM

\begin{tabular}{lrrl}
\hline Sub-basins & Area $\left(\mathbf{k m}^{\mathbf{2}}\right)$ & Total $\mathbf{( \% )}$ & Main basins of the Country \\
\hline Porsuk & 7048.4 & 23.7 & Sakarya \\
Karasu & 4343.3 & 14.7 & Susurluk \\
Emet & 5303.9 & 17.7 & Susurluk \\
Kocacay & 6.7 & Susurluk \\
Simav & 1996.2 & 7.6 & Gediz \\
Seydi & 2291.2 & 3.6 & Sakarya \\
Aksu & 1104.9 & 7.1 & Akarcay \\
Banat & 5.4 & Buyuk Menderes \\
Sarisu & 2077.4 & 3.5 & Sakarya \\
Eynes & 1550.3 & 10.0 & Gediz \\
\hline Total & 1024.8 & $\mathbf{1 0 0 . 0}$ & \\
\hline
\end{tabular}

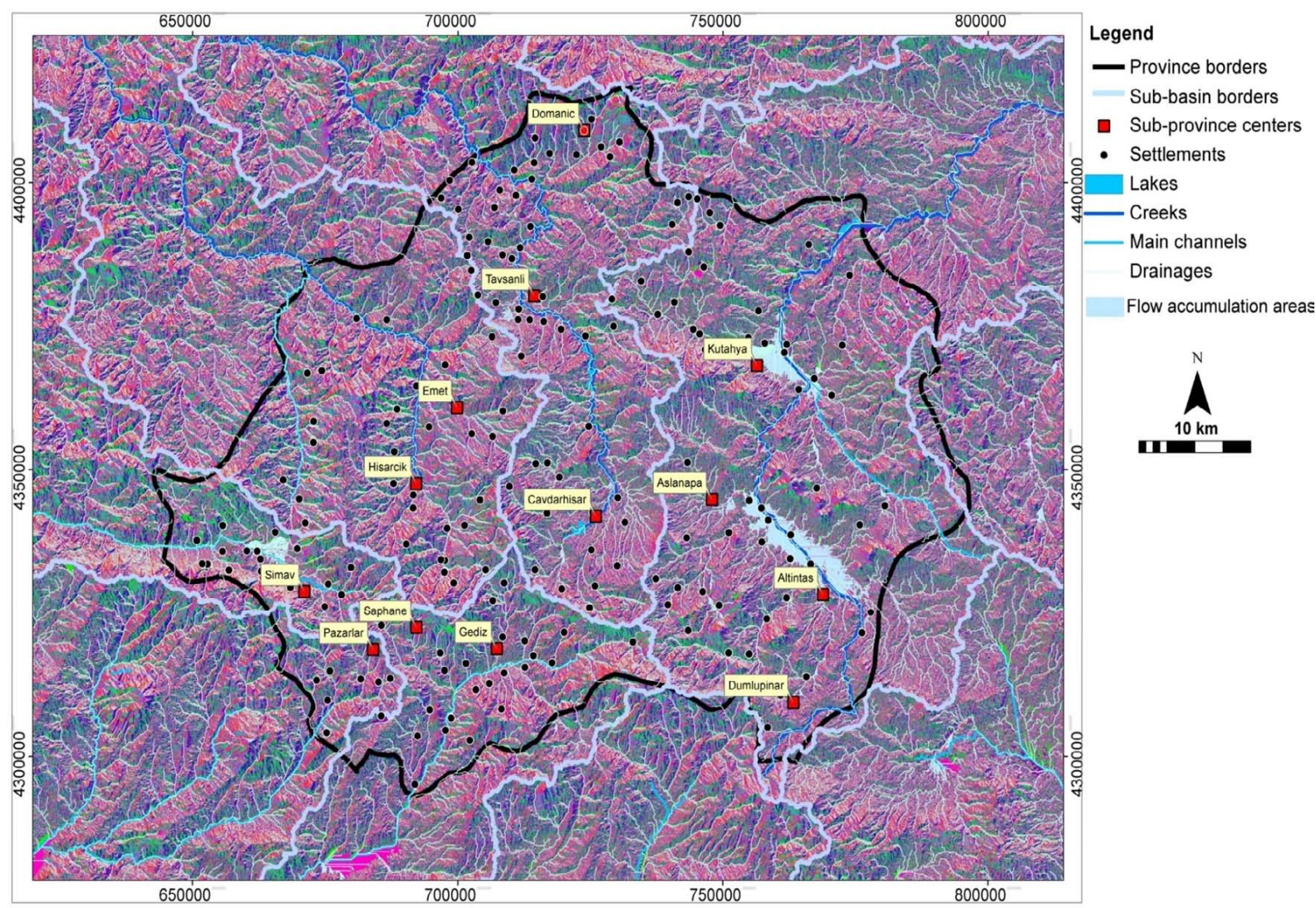

Figure 7. Water flow accumulation areas and main stream drainages overlaid with settlements

This map was used for interpretation of flooding hazard risk. The map indicates that the settlements and the agricultural plains of Kutahya, Altintas and Simav are under higher flooding risk.

The study revealed that the settlements of Gediz, Simav, Kutahya, Emet, Tavsanli, Dumlupinar, Domanic, Hisarcik, Pazarlar, and Saphane (in decreasing order) are most vulnerable to earthquake damage. The $\mathrm{M}=7.1$ Gediz earthquake in 1970 and the $\mathrm{M}=5.9$ Simav earthquake in 2011 demonstrate that Gediz and Simav are at high risk of further earthquakes. The high likelihood of further earthquakes in these areas exists because they are located on the extension of the Aksehir fault zone, which is still tectonically active. 
Moreover, thermal zones are associated with active fault lines, volcanism, and geo-tectonic structures. The thermal zones of Yoncali, Murat, Yesil, Kaynarca, Simav, Tavsanll, and Ilica indicate that these settlements are at risk of earthquake events.

Additionally, the city of Kutahya is located just north of Mount Yellice $(1,764 \mathrm{~m})$. The suburbs and agricultural area surrounding the city are located in hollow (graben) areas that are under the threat of flooding because of large amounts of water flowing from the mountain after heavy rains. Additionally, Kutahya was built on an active fault zone north of Mount Yellice. Therefore, it is perhaps said that Mount Yellice is a horst, while the settlements and agricultural plains are located in graben areas in terms of the earthquake hazard.

Table 4. Risk levels of the flooding and earthquake hazards to the settlements of the Kutahya Province, relative to each other

\begin{tabular}{|c|c|c|c|c|}
\hline $\begin{array}{l}\text { Main } \\
\text { Settlements }\end{array}$ & $\begin{array}{l}\text { Flooding } \\
\text { Risk Level }\end{array}$ & $\begin{array}{l}\text { Earthquake } \\
\text { Risk Level }\end{array}$ & $\begin{array}{l}\text { Population } \\
\text { Year } 2012\end{array}$ & $\begin{array}{l}\text { The Most Severe Earthquakes } \\
\text { (Magnitude and Date in the Past) }\end{array}$ \\
\hline Kutahya & 1 & 2 & 238,000 & $5.0(1970)$ \\
\hline Inkoy & 1 & 2 & 2,500 & \\
\hline Seyitomer & 1 & 2 & 250 & \\
\hline Altintas & 1 & 3 & 18,000 & $5.1(1970)$ \\
\hline Aslanapa & 2 & 3 & 11,000 & $4.6(1971)$ \\
\hline Adakoy & 1 & 3 & 350 & \\
\hline Haydarlar & 1 & 3 & 250 & \\
\hline Nuhoren & 1 & 3 & 250 & \\
\hline Eymir & 1 & 3 & 150 & \\
\hline Cayirbasi & 1 & 3 & 150 & \\
\hline Alayunt & 1 & 3 & 200 & \\
\hline Cavdarhisar & 2 & 3 & 8,000 & $5.5(1970)$ \\
\hline Domanic & 2 & 3 & 16,000 & $6.2(1942)$ \\
\hline Dumlupinar & No & 3 & 3,000 & $5.3(1947)$ \\
\hline Emet & No & 2 & 22,000 & $5.3(1970)$ \\
\hline Gediz & 2 & 1 & 52,000 & $7.1(1970)$ \\
\hline Hisarcik & 2 & 3 & 14,000 & $5.5(1944)$ \\
\hline Pazarlar & No & 3 & 6,000 & $4.2(1956)$ \\
\hline Simav & 1 & 1 & 68,000 & $5.9(2011)$ \\
\hline Gulkoy & 1 & 1 & 250 & \\
\hline Guney & 1 & 1 & 300 & \\
\hline Saphane & No & 3 & 8,000 & $5.5(1970)$ \\
\hline Tavsanli & 2 & 3 & 101,000 & $4.2(1956)$ \\
\hline Gobel & 1 & 3 & 550 & \\
\hline
\end{tabular}

Note that, in general, the locations of the junction points of the main stream channels, where they merge, called pour points, have higher flooding risk. On the other hand, all over Kutahya Province is occupied on the first degree earthquake region according to the earthquake map of Turkey (Tabban, 2000; Yilmaz \& Bagci, 2006; Korkmaz, 2009; AFAD, 2013; KOERI, 2013). 
DEM allows us to quantify the landscape characteristics and to obtain geo-information about the landscape. Any sudden color change on a visualized DEM means that there is a specific elevation change in the topography. Therefore, DEM classification can be used for modeling of landforms.

Fault lines and main river channels are often reflected as landform features on a DTM that shows valleys, plains, plateaus, mountains, ridge-lines, break-lines, lineaments, slope-aspects, collapses, declines, depressions, heights, and rises where any sudden color changes can be observed on the terrain surface. The DEM data can be used for describing risk levels of the flooding and earthquake hazards to settlements by obtaining geo-information and quantifying landscape characteristics from them.

Since damage from flooding and earthquake leads to social and economic costs, scientists have been trying to find ways to prevent or mitigate natural disaster damage. The results of risk interpretation of floods and earthquakes can be used to reduce possible damage in the future by evaluating the geo-information obtained.

In this study, a methodology in Figure 2 was developed by evaluating previous disasters as well as interpreting the existing DEM data, and applied it to extract information of the landscape characteristics, which was used to determine the levels of flood and earthquake risk to the population of Kutahya Province.

Table 4 is produced in order to summarize the status of the settlements, their population, their risk level regarding both earthquake and flooding hazards, and the previous earthquakes in each settlements by the interpretations of the Figures 3-7. The risk levels of the settlements interpreted relative to each other and in a decreasing order from 1 to 3 .

The accuracy of the study depends on the resolution of the grid size of the DEM data, the data quality, and the data processing. The ASTER DEM data used in this study have a spatial resolution of $30 \mathrm{~m}$, with a horizontal accuracy of $15 \mathrm{~m}$ and vertical accuracy of $8 \mathrm{~m}$. If higher resolution DEM such as LIDAR is employed, the methodology will produce more accurate results.

\section{Conclusion}

This study describes flood and earthquake risk interpretation and vulnerability analysis of settlements in the province of Kutahya, Turkey. The interpretation was based on the current dataset of the ASTER GDEM in addition to auxiliary GIS data layers such as the settlements, rivers, river basins, fault zones, thermal zones, and previous earthquake information. The results identify areas at risk of flooding and earthquake damage.

The study's aim was to assist land planning in Kutahya Province by identifying areas that are at risk of flooding and earthquake damage. This was effectively fulfilled using a methodology of determining the structural-geological information, the DTM, and a 3D fly-through dynamic model indicating the landforms, main stream drainages, basins, and water flow accumulation areas of Kutahya Province. The digital terrain analysis was based on the ASTER GDEM data. The results can be helpful in future environmental planning to mitigate the adverse impacts of the natural disasters for Kutahya Province.

The methodology presented in Figure 2 applies quantitative and visual interpretation of the landscape characteristics overlaid with the auxiliary data, showing a good example of data fusion in a GIS implementation. Having obtained geo-information for determining the possible risk levels of flooding and earthquakes in Kutahya Province, the results of this study can contribute to planning and decision-making involved in selection of suitable regional development plan strategies such as determining locations for urban development, airports, dams, bridges, industrial zones, and nuclear power stations. Moreover, the structural-geological information acquired is useful for describing the areas at risk and for environmental planning in Kutahya Province.

The lack of plans and planning approaches for disasters in Turkey is an issue that arises after every disaster. This study identifies the settlements that need to give priority to preparing plans of mitigation, contingency, and flexibility before and after disasters. For example, the study reveals that the settlements of Gediz, Simav, and Kutahya are located in the most vulnerable areas to both flooding and earthquakes; therefore, preparing mitigation and reconstruction plans for natural disasters is a high priority for their local governments.

\section{References}

ArcGIS. (2010). Arc GIS 10.1 Tutorial and Manual (Redland, CA: ESRI). Retrieved from http://www.esri.com

AFAD. (2013). Disaster and Emergency Management Presidency, Earthquake Department (Turkish: Afet ve Acil Durum Yönetimi Başkanlıgi, Deprem Bolumu). Retrieved from http://www.deprem.gov.tr/sarbis/Shared/Default.aspx

ASTER GDEM. (2013). The Advanced Spaceborne Thermal Emission and Reflection, Global Digital Elevation Model data. Retrieved from http://gdem.ersdac.jspacesystems.or.jp/ 
Atalay, I. (2008). Geography of regions in Turkey (in Turkish). Inkilap Press, Ankara.

Band, L. E. (1986). Topographic partition of watersheds with digital elevation models. Water Resources, 22(1), 15-124. http://dx.doi.org/10.1029/WR022i001p00015

Baykan, A. R. (2004). River basins in the Environmental Atlas of Turkey (in Turkish). Retrieved from $\mathrm{http} / / /$ www.cedgm.gov.tr/CED/Files/cevreatlas\%C4\%B1/atlas_metni.pdf

Bilim, F. (2007). Investigations into the tectonic lineaments and thermal structure of Kutahya-Denizli region, western Anatolia, from using aeromagnetic, gravity and seismological data. Physics of the Earth and Planetary Interiors, 165(3-4), 135-146. http://dx.doi.org/10.1016/j.pepi.2007.08.007

Bozkurt, E. (2001). Neotectonics of Turkey - a synthesis. Geodinamica Acta, 14(1-3), 3-30. http://dx.doi.org/10.1016/S0985-3111(01)01066-X

Elmas, N., \& Bentli, I. (2013). Environmental and depositional characteristics of diatomite deposit, Alayunt Neogene Basin (Kutahya), West Anatolia, Turkey. Environmental Earth Science, 68, 395-412. http://dx.doi.org/10.1007/s12665-012-1745-5

ERSDAC. (2013). ASTER global DEM version 2 validation summary report at Earth Remote Sensing Data Analysis Center. Retrieved from http://www.jspacesystems.or.jp/ersdac/GDEM/ver2Validation/Summary_GDEM2_validation_report_final.p $\mathrm{df}$

GEODATA. (2013). Ministry of Forest and Water, GEODATA (Turkish: Orman ve Su Bakanligi). Retrieved from http://geodata.ormansu.gov.tr/3d/indexv5.aspx

HGK. (2013). General Command of Mapping (Turkish: Harita Genel Komutanligi). Retrieved from http://www.hgk.msb.gov.tr/english/index.php

KDEF. (2010). Kutahya Department of Environment and Forestry. Kutahya Provincial Environmental Report of Kutahya. Retrieved from http://cdr.cevre.gov.tr/icd_raporlari/kutahyaicd2009.pdf

KOERI. (2013). Kandilli Observatory Earthquake Research Institute (Turkish: Bogazici Universitesi, Kandilli Rasathanesi Deprem Arastirma Enstitusu). Integrated homogeneous Turkey's Earthquake Catalog. Retrieved from http://www.koeri.boun.edu.tr/sismo/

Korkmaz, K. A. (2009). Earthquake disaster risk asssessment and evaluation for Turkey. Environmental Geology, 57, 307-320. http://dx.doi.org/10.1007/s00254-008-1439-1

Kose, R. (2005). Research on the generation of electricity from the geothermal resources in Simav region, Turkey. Renewable Energy, 30(1), 67-79. http://dx.doi.org/10.1016/j.renene.2004.04.004

Kose, R. (2007). Geo-thermal energy potential for power generation in Turkey: A case study in Simav, Kutahya. Renewable and Sustainable Energy Reviews, 11(3), 497-511. http://dx.doi.org/10.1016/j.rser.2005.03.005

Kutahya Governorship. (2013). Information about the Kutahya province. Retrieved from http://www.kutahya.gov.tr/tab_icerik.php?cat=tarih\&lang=tr\&id=

Mark, D. M., Dozier, J., \& Frew, J. (1984). Automated basin delineation from digital elevation data. Geo-Processing, 2, 299-311. http://dx.doi.org/10.1007/BF00891823

MGM. (2013). Turkish State Meteorological Service (Turkish: Meteoroloji Genel Mudurlugu). Retrieved from http://www.mgm.gov.tr/en-US/forecast-5days.aspx

Mitchell, W. A., \& Glowatski, E. A. (1976). Geography of Kutahya Province, Turkey. Air Force Academy Colorado Springs CO.

MTA. (2013). General Directorate of Mineral Research and Exploration (Turkish: Maden Tetkik ve Arama Genel Mudurlugu). Retrieved from http://www.mta.gov.tr/v2.0/eng/index.php

O'Callaghan, J. F., \& Mark, D. M. (1984). The extraction of drainage networks from digital elevation data. Computer Vision Graph Image Processing, 28, 328-344. http://dx.doi.org/10.1016/S0734-189X(84)80011-0

Ozdemir, H., \& Bird, D. (2009). Evaluation of morphometric parameters of drainage networks derived from topographic maps and DEM in point of floods. Environmental Geology, 56, 405-1415. http://dx.doi.org/10.1007/s00254-008-1235

Penzien, J., \& Hanson, R. D. (1970). The Gediz, Turkey, earthquake of 1970: A report to the National Science Foundation, National Research Council (U.S). Committee on earthquake Inspection, National Academy 
Engineering.

San, B. T., \& Suzen, M. L. (2005). Digital elevation model (DEM) generation and accuracy assessment from ASTER stereo data. International Journal of Remote Sensing, 26(22), 5013-5027, http://dx.doi.org/10.1080/01431160500177620

Tabban, A. (2000). Geology of cities and earthquake condition. The Chamber of Geology Engineering, publishing no: 56, Ankara (in Turkish).

Taymaz, T., Yilmaz, Y., \& Dilek, Y. (2007). The geodynamics of the Aegean and Anatolia: Introduction. Geological Society, London, 291, 1-16. http://dx.doi.org/10.1144/SP291.1

TUIK. (2013). Turkish Statistical Institute (Turkish: Turkiye Istatistik Kurumu). Retrieved from http://www.turkstat.gov.tr

Van der Sande, C. J., de Jong, S. M., \& de Roo, A. P. J. (2003). A segmentation and classification approach of IKONOS-2 imagery for land cover mapping to assist flood risk and flood damage assessment. International Journal of Applied Earth Observation and Geoinformation, 4(3), 217-229. http://dx.doi.org/10.1016/S0303-2434(03)00003-5

Wang, Y., Colby, J. D., \& Mulcahy, K. A. (2002). An efficient method for mapping flood extent in a coastal floodplain using Landsat TM and DEM data. International Journal of Remote Sensing, 23(18), 3681-3696. http://dx.doi.org/10.1080/01431160110114484

Wilson, J. P., \& Gallant, J. C. (2000). Terrain analysis: principles and applications. New York: John Wiley and Sons.

Wolock, D. M., \& Price, C. V. (1994). Effects of digital elevation model map scale and data resolution on a topography-based watershed model. Water Resources, 30(11), 3041-3052. http://dx.doi.org/10.1029/94WR01971

Yilmaz, I., \& Bagci, A. (2006). Soil liquefaction susceptibility and hazard mapping in the residential area of Kutahya (Turkey). Environmental Geology, 49(5), 708-719. http://dx.doi.org/10.1007/s00254-005-0112-1

Zulfikar, C., Kamer, Y., \& Vuran, E. (2011). Kutahya-Simav earthquake report (May 11, 2011). Bogazici University, KOERI, Istanbul. $\quad$ Retrieved from http://www.koeri.boun.edu.tr/depremmuh/raporlar/19-05-2011_Simav_depremi_English.pdf

\section{Copyrights}

Copyright for this article is retained by the author(s), with first publication rights granted to the journal.

This is an open-access article distributed under the terms and conditions of the Creative Commons Attribution license (http://creativecommons.org/licenses/by/3.0/). 